\title{
The Use of the Kohonen Neural Network for Comparing the Declared and Actual State of Knowledge Regarding Reproductive Health and the Impact of Selected Lifestyle Components on Reproductive Health
}

\author{
Marcin Warpechowski ${ }^{1}$, Jędrzej Jan Warpechowski ${ }^{2}$, Marcin Milewski ${ }^{2}$, \\ Adrianna Zańko ${ }^{3}$, Robert Milewski ${ }^{1}$ \\ 1 Department of Statistics and Medical Informatics, Medical University of Bialystok, \\ Poland \\ 2 Scientific Group at Department of Statistics and Medical Informatics, Medical Univer- \\ sity of Bialystok, Poland \\ 3 Doctoral Studies, Medical University of Bialystok, Poland
}

\begin{abstract}
Infertility is a global problem affecting 48 to 186 million couples of reproductive age. In Poland, it concerns approx. 1.5 million couples, which amounts to $20 \%$ of the population capable of reproducing. One of the factors influencing the incidence of fertility disorders may be lifestyle, understood as a multi-disciplinary accumulation of everyday behaviours and habits. In the study, a group of 201 young adults, students of medical and related faculties, were surveyed in order to check the actual level of knowledge about the impact of lifestyle on reproductive health. The Kohonen network, which is an example of a self-learning neural network, was used to find non-obvious connections between the data. The trained Kohonen neural network formed 4 clusters with different characteristics. Based on analyses of the structure of each cluster, it was found that $2^{\text {nd }}$ year students of Medicine are internally divided into 3 fractions. The first fraction declared a high level of knowledge, but did not have real knowledge. The second fraction was aware of their ignorance, as confirmed by the knowledge test. The last fraction was characterized by a high level of self-confidence regarding their knowledge about reproductive health and obtained a high result in the knowledge test. It was confirmed that people studying at the Medical faculty know more than students of the same year at faculties other than Medicine. Interesting results were obtained for a group of $3^{\text {rd }}$ year students of first-cycle studies in Dietetics. They did not obtain a significantly better result in the knowledge test concerning the influence of diet and lifestyle on reproductive health. It would seem that one could expect at least a few highly knowledgeable students in a group of $3^{\text {rd }}$ year students, but this was not confirmed by the study. In view of the obtained results, it was concluded that the Kohonen neural network is applicable to the analysis of data on the actual state of knowledge about the impact of lifestyle on reproductive health.
\end{abstract}


Marcin Warpechowski et al.

\section{Introduction}

The phenomenon of infertility has accompanied mankind from the beginning of its existence. Material traces left by the oldest civilizations prove that fertility was an object of worship for humans. Historically, however, the problem of infertility was only noticed at the time of the collapse of noble houses. The lack of an heir made it impossible to hand over property or authority. If less influential families were unable to conceive a child, infertility became their personal tragedy. With the increase in the average standard of living and the progress in medical sciences, the problem of infertility gradually lost its taboo character, until finally being formally defined in the $20^{\text {th }}$ century (Koperwas \& Głowacka, 2017).

A commonly used definition of infertility is provided by the World Health Organization (WHO). It is defined as the inability to obtain pregnancy for 12 months despite having intercourse 2 to 4 times a week without the use of any contraceptive methods (Koperwas \& Głowacka, 2017; Łukaszuk et al., 2018). In the International Classification of Diseases (IDC), infertility is ranked among social diseases, next to diseases such as obesity, hypertension, and diabetes (World Health Organization, 2009). This means that infertility is a significant health problem. According to WHO estimates, globally it affects between 48 and 186 million couples of reproductive age (World Health Organization, 2021). In Poland, it concerns approx. 1.5 million couples, which amounts to about $20 \%$ of population of reproductive age (Forsal, 2019). It is worth noting that, according to the opinion of the Polish Society of Reproductive Medicine and Embryology and the Polish Society of Gynecologists and Obstetricians, most couples struggling with infertility are not under the specialist care of centres dealing with comprehensive diagnosis and treatment of fertility disorders (Janicka et al., 2012).

The issue of infertility attracts more and more attention in societies of highly developed countries. The inability to conceive a descendant places an enormous psychological burden on infertile couples and is a huge challenge from the point of view of generational change (Koperwas \& Głowacka, 2017). According to the report prepared by the Central Statistical Office of Poland, 334.6 thousand children were born in the country within the last twelve months. The fertility rate was 1.4. Moreover, women in Poland decide to give birth to their first child around the age of 29. In the last three decades, on average, 417 thousand children were born annually, which, compared to the average number of births in the 1980s (665.5 thousand), indicates that it is impossible to recognize a new baby boom. (Główny Urząd Statystycz- 
ny, 2021). The matter of the demographic problem is highly complicated, but in the opinion of many experts, the economic or social factor is not the only reason for the low number of births in Poland.

The basis of infertility is multifactorial and its treatment should always focus on the couple (Górna, 2014; Przysławski et al., 2010). The general causes include unhygienic lifestyle, eating habits, incorrect body weight, inflammation in the body, excessive mental effort, and age (Bojanowska \& Kostecka, 2018; Koperwas \& Głowacka, 2017; Łukaszuk et al., 2018; Mahey et al., 2018). It seems that the influence of some of the elements indicated above can (at a low cost) be partially offset by increasing the awareness of the influence of lifestyle components on reproductive health. Currently, fertility awareness is low, both globally and in Poland (Abolfotouh et al., 2013; Bunting et al., 2013; Czyszewicz et al., 2015; Daniluk \& Koert, 2013; Górna, 2014; Targan et al., 2018). Broadening the knowledge about reproduction and the factors that may have an impact on it (both negative and positive) seems to be particularly important for the professional competences of future doctors and other medical workers. Reliable knowledge about the physiology of human fertility and the way lifestyle influences reproductive health should be widely available to all young adults, especially those studying at medical universities (Targan et al., 2018).

The aim of the study was to demonstrate the usefulness of applying the Kohonen network in comparing the declared and actual state of knowledge about reproductive health and the impact of selected lifestyle components on reproductive health among young adults studying at the Medical University of Bialystok (Poland).

\section{Materials and Methods}

As part of the study, a survey was carried out among people studying at the Medical University of Bialystok (Białystok, Poland), using the proprietary research questionnaire. The questionnaire consisted of two sections of questions. In the first section, the respondents were asked to declare (selfassessment) their current state of knowledge about reproductive health and their current state of knowledge about the impact of lifestyle on reproductive health. The respondents rated themselves on a scale from 1 to 10, where 1 meant very little knowledge, and 10 meant very high knowledge.

Then, the interviewees moved to the section checking the actual state of knowledge about reproductive health and the impact of selected lifestyle 
components on reproductive health. The knowledge verification section consisted of four blocks of questions. In the first block, knowledge about the impact of lifestyle on the physiology of fertility was checked. The second category of questions examined the awareness of the need for testing for potential infertility, depending on the length of the period of unsuccessful attempts to have children. The third block contained questions related to the influence of eating habits on reproductive health. The last block focused on issues related to the routine of everyday life. In it, the awareness of the influence of the respondents' daily habits and behaviour on reproductive health was examined.

The survey covered 201 students of the Medical University in Białystok. The respondents represented various fields and years of study. The most numerous group were $2^{\text {nd }}$ year students of long-cycle studies in Medicine (85 people), $6^{\text {th }}$ year students of long-cycle studies in Medicine (59), $2^{\text {nd }}$ year students of first-cycle studies in Cosmetology (32), and $3^{\text {rd }}$ year students of first-cycle studies in Dietetics (14). A marginal group were students of Biostatistics (6 $2^{\text {nd }}$ year students of first-cycle studies and $51^{\text {st }}$ year students of second-cycle studies). The average age of respondents was 22 years with a standard deviation of 2.82 years. The female gender was almost three times more frequent in the study group than the male gender (152 women, 49 men).

Kohonen neural networks were used to analyse the collected research material. They are an example of self-learning neural networks using the neighbourhood concept (Milewska et al., 2013; Tadeusiewicz \& Szaleniec, 2015). Network learning occurs in an unsupervised manner, i.e. data is entered into the database without a predetermined pattern (Milewska et al., 2013). Patterns are created only during the learning process. Kohonen neural networks are characterized by operation in a multidimensional input data space, which is why the network input contains a significant number of neurons associated with many input signals. Moreover, the topological layer of the Kohonen neural network contains a large number of neurons, which makes it possible for the network, after training, to present very subtle distinctions and classifications of the input data (Milewska et al., 2013; Tadeusiewicz \& Szaleniec, 2015). The approach, proposed by Teuvo Kohonen, has been applied in situations where new relationships are searched for, often undetectable with the standard statistical methods (Milewska et al., 2013). The Statistica 13.3 package by TIBCO Software Inc. was used for calculations. 
The Use of the Kohonen Neural Network for Comparing the Declared...

\section{Results and Discussion}

The Kohonen neural network was trained on the collected data, which classified the analysed cases into four clusters. The implementation of the Kohonen neural network required $15 \%$ of the cases to be reserved for the test and the validation group each, so that the training set accounted for $70 \%$ of all the individuals in the sample, i.e. 141 cases. The classification of the case to a given group was performed randomly.

The sum of the correct answers scored in the knowledge test for each of the blocks of questions, the level of self-assessment of knowledge on the subject of reproductive health, and the influence of lifestyle on reproductive health were analysed. Based on the input data, the Kohonen neural network classified the analysed cases into 4 clusters. The structure of each cluster was analysed in terms of two features of the sample objects, i.e. the field of study and the year of study. Figure 1 shows a box plot describing the declared level of knowledge about reproductive health for each of the clusters.

Figure 2 presents a box plot showing the declared level of knowledge about the impact of lifestyle on reproductive health for each of the clusters.

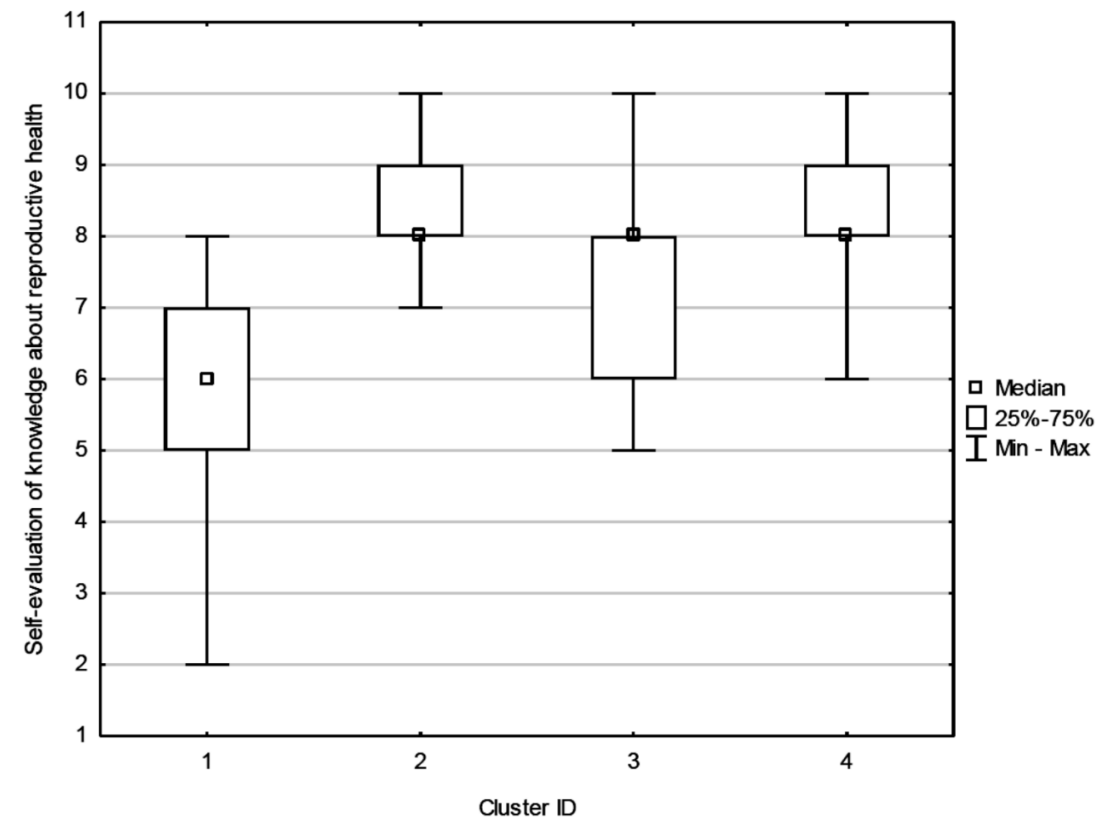

Figure 1. Level of declared knowledge about reproductive health for each cluster 
Marcin Warpechowski et al.

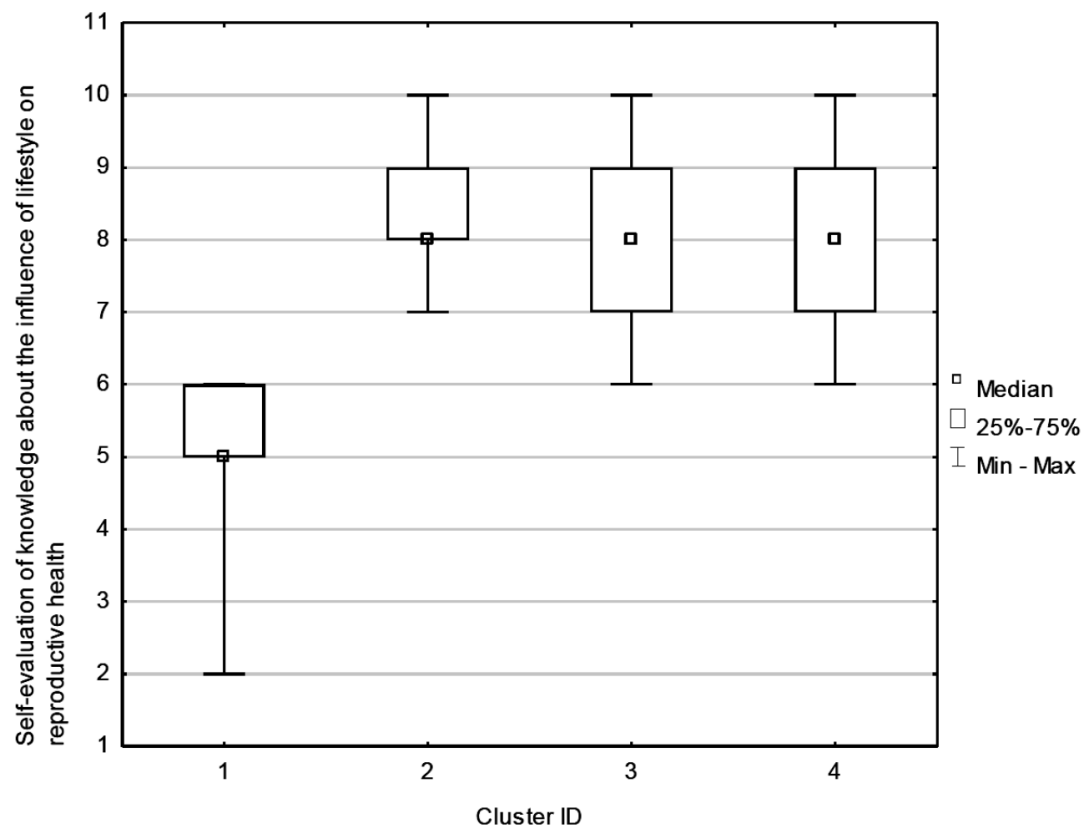

Figure 2. Level of declared knowledge about the impact of lifestyle on reproductive health for each of the clusters

An analysis of figures 1 and 2 shows that the first cluster was characterized by a significantly lower self-confidence compared to the other three clusters. The lower level of self-confidence applies both to knowledge about reproductive health and knowledge about the influence of lifestyle on reproductive health. In the case of knowledge about reproductive health, the median level of self-confidence for the first cluster was $M_{e}=6$ points (Figure 1). In the remaining three clusters, the median was $M_{e}=8$ points (Figure 1). In the case of self-assessment of knowledge about the influence of lifestyle on reproductive health, the median number of points for the first cluster was $M_{e}=5$ points, while in the remaining three clusters it was $M_{e}=8$ points (Figure 2).

On the basis of the distribution of the level of self-confidence in individual clusters, it can be safely concluded that the first cluster included individuals aware of their slightly lower level of knowledge. This may be a group of people in the early stages of their studies who understand the meaning of learning. The other three clusters seem to be confident in their knowledge. These may include individuals interested in reproductive health, people with specialist knowledge, and final-year students. 
The Use of the Kohonen Neural Network for Comparing the Declared...

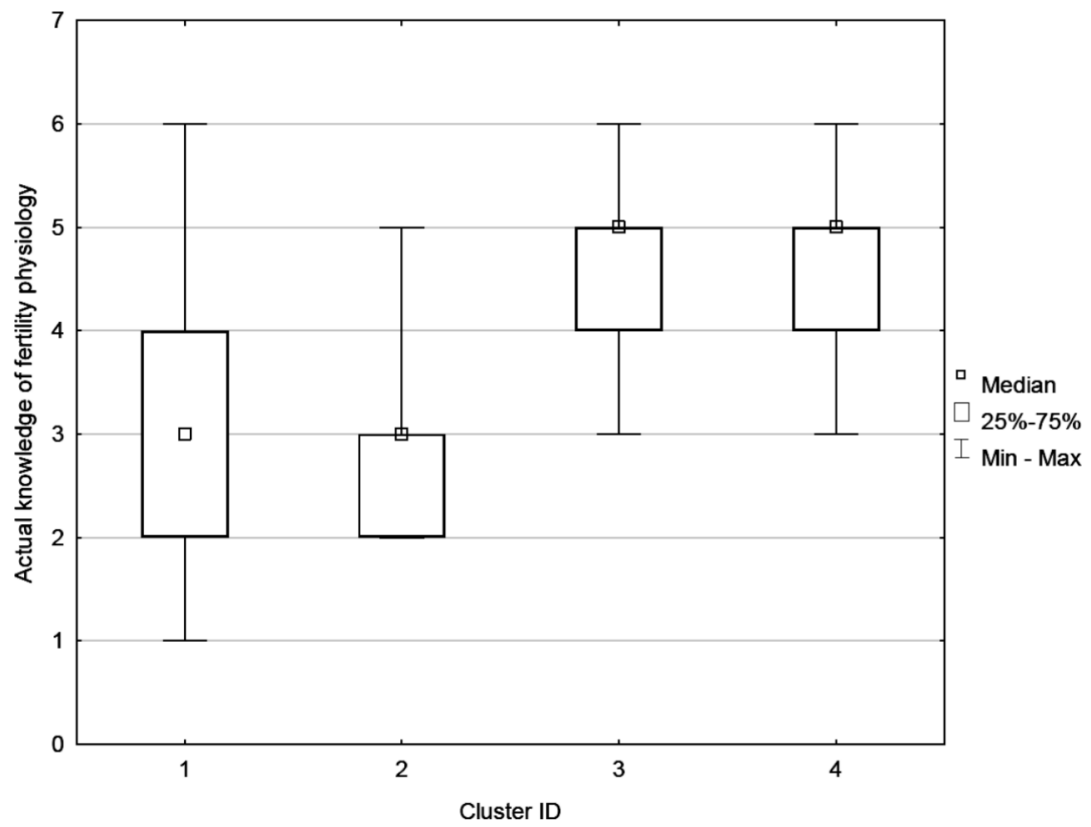

Figure 3. Level of actual knowledge about the physiology of fertility for each cluster

Then, the actual state of the students' knowledge was analysed. Figure 3 shows the actual knowledge about the physiology of fertility for each of the clusters.

Figure 4 shows the sum of the points obtained for the questions assessing the awareness of the need for testing for potential infertility depending on the length of the period of unsuccessful efforts to have a child for each of the clusters.

Figure 5 shows the sum of points scored in the knowledge test concerning the influence of diet on reproductive health.

Figure 6 shows the actual state of knowledge about the impact of everyday behaviour and habits on reproductive health.

When assessing the actual state of knowledge for each of the clusters in the knowledge test, significantly better results were obtained in clusters III and IV. In the knowledge test that included questions about the physiology of fertility, the median for the points scored in clusters I and II was $M_{e}=3$ points, while in clusters III and IV the median was significantly higher at $M_{e}=5$ points; the maximum number of points to be scored was 7 (Figure 3). 
Marcin Warpechowski et al.

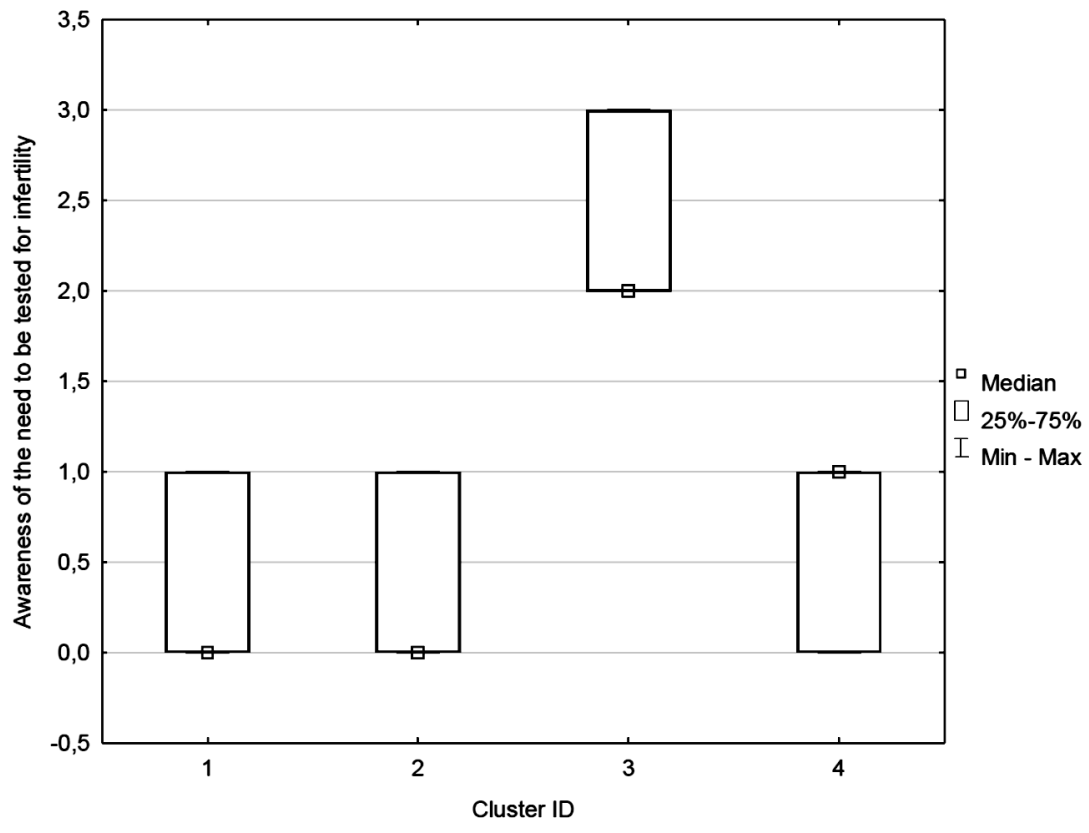

Figure 4. Level of actual knowledge about the need for testing for infertility

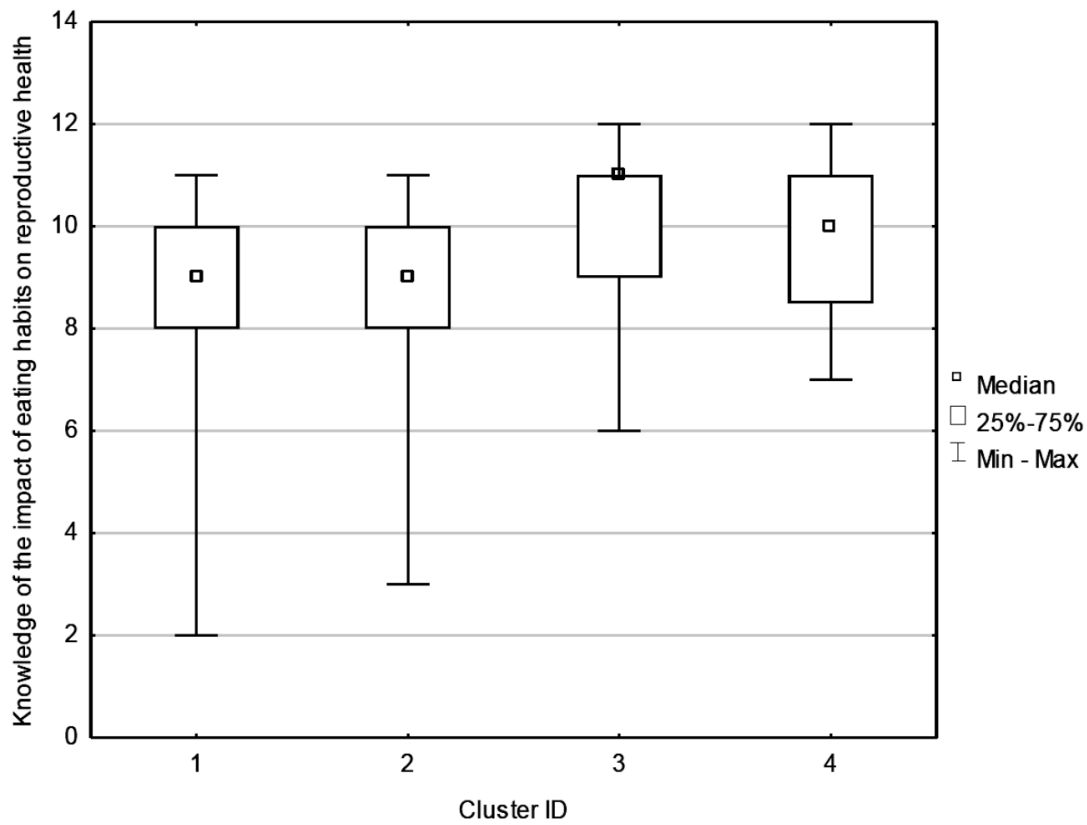

Figure 5. Level of actual knowledge about the effects of diet on reproductive health 
The Use of the Kohonen Neural Network for Comparing the Declared...

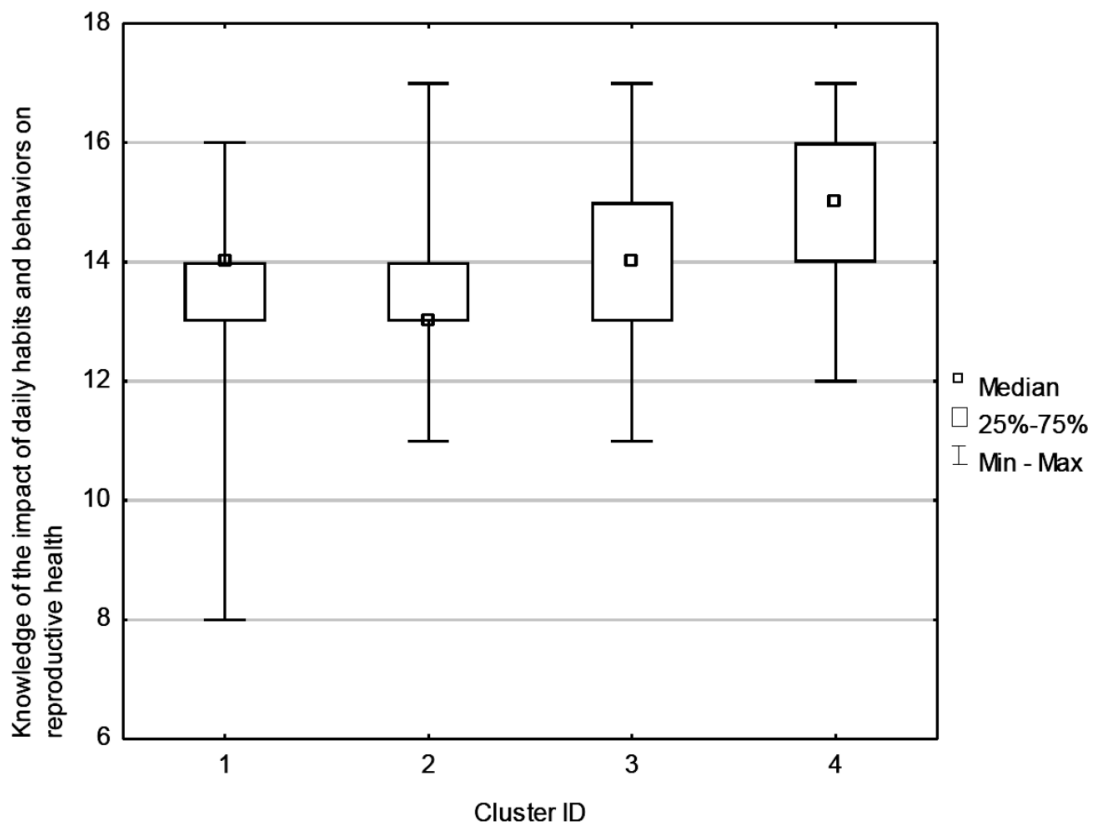

Figure 6. Level of actual knowledge about the impact of everyday behaviour and habits on reproductive health

Respondents from clusters I and II were not aware of the length of the period of ineffective efforts to have a child after which they should be tested for infertility (Figure 4). The median of points scored in clusters I and II was $M_{e}=0$ (Figure 4). Individuals from cluster IV were slightly more aware $\left(M_{e}=1\right)$ (Figure 4). Significantly better results were recorded in cluster III; the median of points scored was $M_{e}=2$ (Figure 4). The maximum number of points was 3 . It is worth mentioning that the minimum number of points scored (Min $=2$ ) in cluster III was equal to the median (Figure 4).

In the test assessing the actual state of knowledge about the impact of eating habits on reproductive health, the differences in scores between the four clusters were slightly less pronounced (Figure 5). The median of correct responses in clusters I and II was $M_{e}=9$ points (Figure 5). In cluster IV, this median was slightly higher at $M_{e}=10$ points (Figure 5). The highest value of the median for correct answers was obtained in cluster III ( $M_{e}=11$ points); the maximum number of points to be scored was 12 .

In the knowledge test concerning the impact of daily habits and behaviour of the respondents on reproductive health, the lowest median values for correct answers were observed in cluster II ( $M_{e}=13$ points) (Figure 6). In clusters I and III, the median was slightly higher at $M_{e}=14$ points. 
The highest values for correct answers were recorded in cluster IV, where the median was $M_{e}=15$ points. In the block of questions concerning the influence of daily habits and behaviour on reproductive health, the maximum score was 17.

By thoroughly analysing the levels of declarative knowledge and the actual state of knowledge, conclusions can be safely made about the structure of each cluster. Clusters III and IV turned out to be those with a high level of knowledge. Individuals belonging to the aforementioned clusters were characterized by a significantly higher level of knowledge and high self-confidence. This means that people in clusters III and IV were aware of their knowledge. Clusters I and II were characterized by a lower level of knowledge compared to clusters III and IV. Self-assessment of knowledge of the individuals belonging to cluster I was consistent with the actual state of knowledge. People from cluster I were aware of their ignorance, which was confirmed by the test results.

Cluster II seems to be an interesting case. The individuals grouped in it declared a high level of knowledge about the subject of reproductive health as well as about the impact of lifestyle on reproductive health. At the same time, the cluster was characterized by a low level of knowledge, which is a significant aspect, i.e. the people in cluster II claimed to have extensive knowledge, while in fact their knowledge was poor.

Table 1 shows the relationship between clusters, the analysed fields of study and years of study.

Analysing the data collected in table 1, it can be concluded that in cluster I, $51.4 \%$ of all the individuals were $2^{\text {nd }}$ year students of long-cycle studies in Medicine (18 out of 35 people). The second largest group in cluster I were $2^{\text {nd }}$ year students of first-cycle studies in Cosmetology (12 out of 35 people, representing $34.3 \%$ of the entire cluster). Cluster II were mainly $2^{\text {nd }}$ year students of Medicine (29 out of 47 people, representing $61.7 \%$ of the cluster). The majority ( 6 out of 11 people) of $3^{\text {rd }}$ year students of first-cycle studies in Dietetics (12.8\% of the entire cluster) and 6 of the $212^{\text {nd }}$ year students of first-cycle studies in Cosmetology (12.8\% of the entire cluster) were also included in cluster II.

Furthermore, it can be seen that cluster III is almost exclusively composed of $6^{\text {th }}$ year students of long-cycle studies in Medicine (14 out of 19 people, representing $73.7 \%$ of cluster III). Cluster IV included mainly $6^{\text {th }}$ year students of long-cycle studies in Medicine (23 out of 40 people, representing $57.5 \%$ of the cluster). The second largest group in cluster IV were $2^{\text {nd }}$ year students of long-cycle studies in Medicine (10 out of 40 people, representing $25 \%$ of the entire cluster). 
The Use of the Kohonen Neural Network for Comparing the Declared...

Table 1. Cluster characteristics obtained with Kohonen Networks

\begin{tabular}{|c|c|c|c|c|}
\hline \multirow{3}{*}{ Field, year, level of study } & \multicolumn{4}{|c|}{ Clusters } \\
\hline & I & II & III & IV \\
\hline & \multicolumn{4}{|c|}{ Share of respondents in the cluster (per cent) } \\
\hline Cosmetology, $2^{\text {nd }}$ year, Bachelor degree & $\begin{array}{c}12 \\
(34.29)\end{array}$ & $\begin{array}{c}6 \\
(12.77)\end{array}$ & $\begin{array}{c}1 \\
(5.26)\end{array}$ & $\begin{array}{c}2 \\
(5.00)\end{array}$ \\
\hline Medicine, $2^{\text {nd }}$ year, long-cycle studies & $\begin{array}{c}18 \\
(51.43)\end{array}$ & $\begin{array}{c}29 \\
(61.70)\end{array}$ & $\begin{array}{c}1 \\
(5.26)\end{array}$ & $\begin{array}{c}10 \\
(25.00)\end{array}$ \\
\hline Biostatistics, $2^{\text {nd }}$ year, Bachelor's degree & $\begin{array}{c}2 \\
(5.71)\end{array}$ & $\begin{array}{c}2 \\
(4.26)\end{array}$ & $\begin{array}{c}2 \\
(10.53)\end{array}$ & $\begin{array}{c}0 \\
(0)\end{array}$ \\
\hline Biostatistics, $1^{\text {st }}$ year, Master's degree & $\begin{array}{c}0 \\
(0)\end{array}$ & $\begin{array}{c}1 \\
(2.13)\end{array}$ & $\begin{array}{c}1 \\
(5.26)\end{array}$ & $\begin{array}{c}2 \\
(5.00)\end{array}$ \\
\hline Dietetics, $3^{\text {rd }}$ year, Bachelor's degree & $\begin{array}{c}2 \\
(5.71)\end{array}$ & $\begin{array}{c}6 \\
(12.77)\end{array}$ & $\begin{array}{c}0 \\
(0)\end{array}$ & $\begin{array}{c}3 \\
(7.50)\end{array}$ \\
\hline Medicine, $6^{\text {th }}$ year, long-cycle studies & $\begin{array}{c}1 \\
(2.86)\end{array}$ & $\begin{array}{c}3 \\
(6.38)\end{array}$ & $\begin{array}{c}14 \\
(73.68)\end{array}$ & $\begin{array}{c}23 \\
(57.50)\end{array}$ \\
\hline Total (n) & 35 & 47 & 19 & 40 \\
\hline
\end{tabular}

$6^{\text {th }}$ year Medicine students practically did not participate in clusters I and II. This confirms their high level of knowledge about reproductive health, the awareness of the impact of lifestyle on reproductive health, and the adequate self-confidence. The frequency distribution of answers provided by $3^{\text {rd }}$ year students of first-cycle studies in Dietetics seems puzzling. It would seem that a group of $3^{\text {rd }}$ year students should include some outstanding individuals (clusters III and IV were clusters characterized by a really high level of knowledge). However, $3^{\text {rd }}$ year students of firstcycle studies in Dietetics did not score significantly more points in the block of questions dealing with the issue of the impact of diet on reproductive health. In view of this conclusion, it can be said that it would be a good idea to survey second-cycle students of Dietetics at the Medical University of Bialystok.

A specific frequency distribution of occurrences in clusters can be observed for $2^{\text {nd }}$ year Medicine students. This specificity consists in triple distribution, i.e. three subgroups are observed for $2^{\text {nd }}$ year Medicine students. The first subgroup consists of people whose actual knowledge about reproductive health and the impact of lifestyle on reproductive health is high, as is their level of declarative knowledge (they constitute $25 \%$ of cluster IV). The second subgroup consists of people who do not have extensive knowledge, but are aware of their ignorance. Such persons are present in cluster I, 
constituting $51.4 \%$ of the cluster. The third subgroup is represented by people who declare a high level of knowledge, but do not really have the knowledge. These may be people characterized by a generally high level of self-esteem and above-average self-confidence. On the other hand, the group may consist of people exhibiting "know-it-all" character traits.

\section{Conclusions}

Kohonen neural networks can be successfully used to find non-obvious similarities in sets of analysed data. An analysis of the internal structure of the clusters made it possible to recognize three subgroups among $2^{\text {nd }}$ year students of Medicine, which would be difficult to achieve with the use of standard statistical tests. It has been confirmed that $2^{\text {nd }}$ year students of Medicine have a higher level of knowledge than students of the same year studying in a field other than Medicine. Comparing the structure of cluster IV and III with cluster II, it seems that $2^{\text {nd }}$ year students of Medicine who are characterized by a high level of self-confidence, but with a low level of knowledge, learn as they complete the successive stages of the programme, which may well prove the level of education inherent in the indicated field of study. At the same time, it can be stipulated that this inference requires further verification. On the basis of the obtained results, it seems justified to continue research with the application of the Kohonen neural network on a much larger set of data.

\section{R E F E R E N C E S}

Abolfotouh, M. A., Alabdrabalnabi, A. A., Albacker, R. B., Al-Jughaiman, U. A., \& Hassan, S. N. (2013). Knowledge, attitude, and practices of infertility among Saudi couples. International Journal of General Medicine, 6, 563573. doi: https://doi.org/10.2147/IJGM.S46884

Bojanowska, M., \& Kostecka, M. (2018). Dieta i styl życia jako czynniki wpływające na płodność. Kosmos - Problemy Nauk Biologicznych, 67(2), 425-439.

Bunting, L., Tsibulsky, I., \& Boivin, J. (2013). Fertility knowledge and beliefs about fertility treatment: findings from the International Fertility Decision-making Study. Human Reproduction, 28(2), 385-397. https://doi.org/10.1093/hum rep/des402

Czyszewicz, A., Grudowska, J., \& Florjański, J. (2015). Poziom wiedzy na temat płodności i jej zaburzeń - badanie ankietowe studentek sześciu wrocławskich uczelni. Pielegniarstwo i Zdrowie Publiczne, 5(3), 223-229. 
Daniluk, J. C, \& Koert, E. (2013). The other side of the fertility coin: a comparison of childless men's and women's knowledge of fertility and assisted reproductive technology. Fertil Steril., 99(3), 839-846.

Forsal (2019). Epidemia bezpłodności. Co 6. para w Polsce ma problemy z poczęciem dziecka, Retrieved from: www.forsal.pl/artykuly/1412298,epidemiabezplodnosci-co-6-para-w-polsce-ma-problemy-z-poczeciem-dziecka.html

Główny Urząd Statystyczny, Departament Badań Demograficznych. (2021). Ludność. Stan $i$ struktura oraz ruch naturalny $w$ przekroju terytorialnym w 2020 r. (stan w dniu 31.12.2020). Warszawa. Retrieved from: https://stat. gov.pl/obszary-tematyczne/ludnosc/ludnosc/ludnosc-stan-i-struktura-lud nosci-oraz-ruch-naturalny-w-przekroju-terytorialnym-stan-w-dniu-31-122020,6,29.html\#

Górna, I. (2014). Wpływ sposobu żywienia oraz wybranych parametrów stylu życia na płodność i rozrodczość kobiet (Rozprawa doktorska, Uniwersytet Medyczny im. Karola Marcinkowskiego w Poznaniu Wydział Farmaceutyczny). Retrieved from: https://www.wbc.poznan.pl/dlibra/publication/416280

Janicka, A., Spaczyński, R., \& Kurzawa, R. (2015). Assisted reproductive medicine in Poland - Fertility and Sterility Special Interest Group of the Polish Gynaecological Society (SPiN PTG) 2012 report. Ginekologia Polska, 86(12). doi: $10.17772 / \mathrm{gp} / 60549$

Koperwas, M., \& Głowacka, M. (2017). Problem niepłodności wśród kobiet i mężczyzn - epidemiologia, czynniki ryzyka i świadomość społeczna. Aspekty Zdrowia i Choroby, 2(3), 31-49.

Łukaszuk, K., Kozioł, K., Jakiel, G., Jakimiuk, A., Jędrzejczak, P., Kuczyński, W., Kurzawa, R., Pawelczyk, L. et al. (2018), Diagnostics and infertility treatment - recommendations of the Polish Society of Reproductive Medicine and Embryology (PSRME) and the Polish Society of Gynecologists and Obstetricians (PSGO). Ginekologia i Perinatologia Praktyczna, 3(3), 112-140.

Mahey, R., Gupta, M., Kandpal, S., Malhotra, N., Vanamail, P., Singh, N. \& Kriplani, A. (2018). Fertility awareness and knowledge among Indian women attending an infertility clinic: a cross-sectional study. BMC Women's Health, 18(177). doi: https://doi.org/10.1186/s12905-018-0669-y

Milewska, A. J., Jankowska, D., Cwalina, U., Więsak, T., Citko, D., Morgan, A., \& Milewski R. (2013). Analyzing Outcomes of Intrauterine Insemination Treatment by Application of Cluster Analysis or Kohonen Neural Networks. Studies, Studies in Logic, Grammar and Rhetoric, 35(48), 7-25.

Przysławski, J., Górna, I., Florek, E., \& Szymanowski, K. (2010). Rola wybranych składników pożywienia w profilaktyce niepłodności u kobiet. Bromatologia i Chemia Toksykologiczna, 53(2), 138-144.

Tadeusiewicz, R., \& Szaleniec, M. (2015). Leksykon sieci neuronowych. Wrocław: Wydawnictwo Fundacji "Projekt Nauka". 
Marcin Warpechowski et al.

Targan, M., Świetlik, D., Kicińska, A., Kardasz, K., \& Wierzba, T. (2018). Wiedza studentów trójmiejskich uczelni wyższych na temat fizjologii prokreacji oraz metod rozpoznawania płodności. Fides Ratio, 35(3), 55-69.

World Health Organization. (2009). International Statistical Classification of Diseases and Related Health Problems, ICD-10, Volume I. Retrieved from: https: //www.who.int/classifications/icd/ICD10Volume2_en_2010.pdf

World Health Organization. (2021). WHO laboratory manual for the examination and processing of human semen. Sixth edition. Retrieved from: https:// www.who.int/publications/i/item/9789240030787 